\title{
Climate change impacts and adaptation of commercial marine fisheries in Australia: a review of the science
}

\author{
Neil J. Holbrook • Johanna E. Johnson
}

Received: 8 July 2013 / Accepted: 9 March 2014 / Published online: 9 April 2014

(C) The Author(s) 2014. This article is published with open access at Springerlink.com

\begin{abstract}
Commercial marine fishing contributes significantly to the Australian economy, and has great importance for coastal communities. However, climate change presents significant challenges for Australia's fishing industries, now and into the future. With greater use of targeted information, the fishing industry will be better placed to minimise the negative impacts and take advantage of opportunities associated with the effects of climate change. The future of the fishing industry - specifically wild capture fisheries - will depend on its ability and capacity to apply appropriate adaptation strategies for its viability and sustainability in the long-term. Knowledge regarding expected long-term changes in species distributions, improved weather and seasonal climate forecasts and their influence on target species, and better understanding of species tolerances, can inform adaptation responses. This paper provides a review of recent advances in research addressing Australia's priorities in relation to commercial marine fisheries' responses to current and anticipated future climate change impacts, and considers barriers and adaptation options for fisheries management over the nearterm planning horizon of 5-7 years.
\end{abstract}

\section{Introduction}

Commercial marine fishing is an important sector of the Australian economy. The Australian Bureau of Agricultural and Resource Economics and Sciences estimate the gross value of production of commercial fisheries and aquaculture in 2009/10 was $\sim$ AUD 2.18 billion. Of this, AUD 1.2 billion was exported in 2009/10 (ABARES 2011), and AUD 1 billion in 2008 (estimate by the Food and Agriculture Organization (FAO); Ridge-Partners 2010). Marine

\footnotetext{
N. J. Holbrook $(\bowtie)$

Institute for Marine and Antarctic Studies, University of Tasmania, Private Bag 129, Hobart, TAS 7001, Australia

e-mail: Neil.Holbrook@utas.edu.au

N. J. Holbrook

Adaptation Research Network for Marine Biodiversity and Resources, Hobart, Australia

J. E. Johnson

C2O Consulting, Cairns, QLD, Australia

J. E. Johnson

School of Marine and Tropical Biology, James Cook University, Townsville, QLD 4810, Australia
} 
fishing activities (including trapping and Indigenous hunting) provided employment for 7,646 people in 2009/10, a $24 \%$ increase from the previous year, and indirectly employed 6,203 people in seafood wholesaling and processing in 2006 (ABARES 2011).

It is anticipated that marine fisheries will be directly affected by climate-related stresses through changes and access to fisheries resources, and indirectly through habitat changes. Such climate change impacts are already being observed in Australia with changes to fish habitats and distribution (e.g. Hallegraeff 2010; Last et al. 2011; Johnson et al. 2011; Pearce et al. 2011; Poloczanska et al. 2009, 2012), and ability to operate in suitable fishing grounds (Tobin et al. 2010). The magnitude of future impacts, and whether marine ecosystems and fisheries can adapt, depends on the rate of change, the response of the marine system to climate change, and other drivers; social (e.g. markets, policy, governance and management) and ecological (e.g. habitat declines and pollution). The adaptation pathways chosen will be critical to the future sustainability of fisheries and will need to consider strategies that are both autonomous (e.g. fish moving to cooler waters) and planned (e.g. factoring climate impacts into stock assessments). Deliberate adaptation that seeks to avoid possible maladaptation requires consideration of: (i) which species, communities or ecosystems are most vulnerable to climate change; (ii) the likelihood of climate-related ecological changes affecting dependent industries; and (iii) what planned adaptations can be implemented to effectively respond to future change.

This review provides a synthesis of the recent published literature relevant to: climate change impacts on, and adaptation of, commercial marine fishing in Australia; how fisheries industries can adapt; and barriers to adaptation. Specifically, it represents key findings of a larger initiative to assess whether research priorities identified in Australia's National Climate Change Adaptation Research Plan for Marine Biodiversity and Resources (Mapstone et al. 2010) are being addressed. Further, it complements a review of climate change science for marine biodiversity conservation (Johnson and Holbrook 2014). Ultimately, research will need to remain committed to addressing climate change impacts and adaptation knowledge gaps so appropriate and effective 'no regrets' adaptation strategies can be applied in the future.

\section{Observed and anticipated impacts of climate change}

Fisheries climate change 'hotspots' have been identified in Australia's southeast and tropical north - with surface and upper ocean temperatures in the southeast increasing at $\sim 3-4$ times the global average rate (Holbrook and Bindoff 1997; Ridgway 2007). These represent locations where significant changes for marine and estuarine species are occurring (Stuart-Smith et al. 2009; Booth et al. 2011). Temperate fish stocks off southeast Australia are likely to change as a result of climate change, particularly through the direct effects of exposure to increasing ocean temperature affecting species with limited thermal ranges, and indirectly through poleward movement of species (Hobday and Poloczanska 2010; Koehn et al. 2011), habitat changes, and increasing disease outbreaks (Danovaro et al. 2010).

Evidence of climate-related impacts on species distributions is emerging in Australia through a number of studies. Ling et al. (2009) documented the expansion of long-spined sea urchins (Centrostephanus rodgersii) in Tasmania from New South Wales (NSW) that are altering benthic habitats critical for valuable rock lobster (Jasus edwardsii) and abalone (Haliotis rubra, H. laevigata) fisheries. Distributional shifts attributed to warming temperate oceans are documented by: Last et al. (2011), with 45 fish species shifted south since the late 1800s; Stuart-Smith et al. (2009), noting that although Tasmanian rocky reef community structure remains unchanged, there have been southern range shifts (e.g. whiting Siphonognathus attenuates and luderick Girella tricuspidata) and new records (e.g. rock cale 
Aplodactylus lophodon); Pitt et al. (2010), who document range shifts in 16 species of Tasmanian invertebrates; and Johnson et al. (2011), who show cascading effects of ecological change in benthic (rocky reef) and pelagic systems. Community monitoring in Tasmania has recorded marine species that have extended their ranges, including eastern blue groper (Achoerodus viridis), eastern rock lobster (J. verreauxi), mahi mahi (Coryphaena hippurus) and grey morwong (Nemadactylus douglasii). ${ }^{1}$

Dang et al. (2012) note that water temperature and immune response in commercial abalone (Haliotis rubra, H. laevigata) in South Australia are correlated, providing some indirect evidence for the possible physiological effects of climate change on fish species. Pecl et al. (2009) conclude that climate change (particularly ocean warming) is expected to have a significant impact on the Tasmanian rock lobster (J. edwardsii) fishery, causing declines in biomass and recruitment in northern Tasmania by 2030 under the IPCC SRES A1B ('businessas-usual') emissions scenario, and in southern regions by 2070 under the A1B and A1FI (fossil intensive) scenarios. This is supported by current catch rate monitoring showing a long-term trend of decline, which is expected to continue. A study of banded morwong (Cheilodactylus spectabilis) metabolic rate in the Tasman Sea shows increased growth in the middle of their range but reduced growth at the northern edge coinciding with warmer ocean temperatures, potentially leading to declining productivity and range contraction (Neuheimer et al. 2011). Similarly, higher ocean temperatures are shown to result in earlier age at maturity and higher natural mortality of species (Froese and Binohlan 2000; Gardner et al. 2011).

Recent studies document the relationships between catch rates and climate variables. A study of school prawns (Metapenaeus macleayi) in northern NSW found that growth and movement were affected by river discharge, with higher discharge rates usually resulting in increased commercial catches (Ives et al. 2009). Meynecke and Lee (2011) show positive correlations between commercial catches of barramundi (Lates calcarifer), mud crabs (Scylla serrata), sea mullet (Mugil cephalus), dusky flathead (Platycephalus fuscus), whiting (Sillago spp.), tiger prawns (Penaeus monodon, P. semisulcatus) and endeavour prawns (Metapenaeus endeavouri, M. ensis) with sea surface temperature and rainfall on the Queensland coast. Similarly, NSW commercial fisheries data show that catch-per-unit-effort (CPUE) increased in proportion to freshwater flow for four commercial estuary species (dusky flathead, luderick G. tricuspidata, sand whiting S. ciliata and sea mullet) and decreased during drought (Gillson et al. 2009). Booth et al. (2011) find similar relationships, with increases in overall CPUE of the northern mud crab fishery interpreted as a response to sea temperature increases.

Alternatively, negative impacts through indirect effects from climate-related habitat loss or degradation are also likely to be very important. For example, studies of seaweed-an important component of temperate rocky reefs-show that bleaching as a result of temperature-mediated disease (Campbell et al. 2011) and southern distributional shifts over the last 40 years (Wernberg et al. 2011) are likely to have implications for habitat-dependent fish.

Tropical fisheries that target species dependent on habitats such as coral reefs, mangroves and seagrass (e.g. prawns, mud crabs, coral trout and aquarium species), are likely to change as a result of climate-related impacts on these habitats (Badjeck et al. 2010; MacNeil et al. 2010; Donnelly 2011; Pratchett et al. 2011a; Bell et al. 2013). For example, barramundi (L. calcarifer) landings correlated with an index of climate variability (Balston 2009a) flag the possible effects on early life stages as rainfall, river flow and temperature variability influence nutrient availability and nursery habitat productivity (Balston 2009b). Coral reef fisheries are likely to be affected by future reductions in population connectivity due to ocean

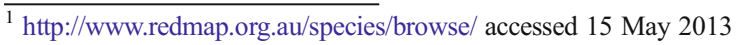


warming accelerating larval development, with possible earlier settlement to reefs that will reduce dispersal distances. This is expected to reduce the spatial scale of connectivity and, in conjunction with increased habitat fragmentation due to coral bleaching and ocean acidification, potentially affect catch rates and species availability as reef fish community composition changes (Munday et al. 2009). Further, habitat associations and community dynamics are high priority research gaps that need to be addressed to better understand the impacts of climate change on coral reef fish (Wilson et al. 2010).

Climate change is expected to affect species populations, communities, ecosystem function, and ultimately fishery stocks (Pörtner and Peck 2010; Bell et al. 2013), and recent modelling supports this. Models of future climate change effects on 12 coastal marine food webs in Australia under the A2 emissions scenario over the next 50 years project some increases in coastal primary production in tropical Australia and minor increases in the southeast and southwest, which could benefit fisheries catches and value (Brown et al. 2010). More recent ecosystem model projections suggest an ecosystem regime shift in southeast Australia by 2060 (under the A2 scenario), with primary producers and pelagic systems likely to benefit from climate change, while demersal systems will most likely decline (Fulton 2011). Projections for the wider Pacific region are that oceanic fisheries (primarily tuna) are expected to shift their distribution - following moving productivity hotspots - and become more abundant in the east, while coastal fisheries are likely to decline (Bell et al. 2013). Pelagic fisheries in Australia target 14 large pelagic species using longline that are projected to experience changes in distribution and abundance as their core habitats move south and contract (Hobday 2010).

Projections (A1B scenario) of global catch potential from 2005 to 2055 show an average of $30-70 \%$ increase in high latitude regions and a $\sim 0 \%$ decline in the tropics (Cheung et al. 2010). Further modelling by Cheung et al. (2011) projects that these fishery catch potentials may be reduced by an additional $\sim 10 \%$ with the inclusion of biogeochemical factors (under the A1B scenario by 2050). Although caution should be exercised in translating these results to the Australian context (Fulton 2011), there are implications for fisheries targeting species at the edge of their range, particularly in tropical regions where Australia may become a last refuge for Indo-West Pacific species as the oceans warm (Hobday and Poloczanska 2010). There is now evidence that fisheries distributions are changing due to ocean warming, with catch data from 1970 to 2006 showing that mean temperature of catch has increased globally in 52 large marine ecosystems, and is significantly positively related to increasing ocean temperature (Cheung et al. 2013).

Observational and modelling studies suggest that the greatest impacts of climate change on fishery stocks are likely to manifest in southeast Australian marine waters (Hobday and Poloczanska 2010), and for some fisheries in tropical regions (Pratchett et al. 2009, 2011a). The nexus between tropical and temperate systems - the subtropics - is an important zone also likely to experience changes to species abundances and community composition. The fisheries stocks most at risk are those dependent on vulnerable habitats (Koehn et al. 2011), cool temperate endemic species (Hobday and Poloczanska 2010), and demersal species (Barange and Perry 2009; Pratchett et al. 2011b), with some shifts in distribution, physiology and catch rates already observed.

\section{What are the indirect effects of climate change on fisheries?}

Coastal areas in tropical Australia are projected to experience more intense weather events that can reduce fishing time, as well as destroy or damage fishery assets and infrastructure such as landing sites, boats and gear (Daw et al. 2009; Badjeck et al. 2010). Increased storm and wave 
activity may reduce the: (i) number of fishing days, (ii) ability to reach some locations, and (iii) seasonal availability of fish (Hobday and Poloczanska 2010). As an example, the effects of two severe tropical cyclones (Tropical Cyclone (TC) Hamish and TC Justin) on fish abundance, catch composition and catch rates of the coral reef finfish fishery in the Great Barrier Reef (GBR) were that $66 \%$ of the reef structure had been damaged but there was no measurable change in the associated fish community and abundance (Tobin et al. 2010). However, depressed fisheries catches of target species (coral trout Plectropomus leopardis and red throat emperor Lethrinus miniatus) by $>30 \%$ lagged up to 9 months post-cyclone. This reduced 'catchability' of fish is uncorrelated with abiotic data such as reef structural damage or sea temperature. TC Justin, on the other hand, resulted in depressed catch rates by up to $50 \%$ for coral trout, accompanied by $200 \%$ increase in red throat emperor catch related to a cool-water event following the cyclone. These results demonstrate how extreme weather events can significantly reduce fishing opportunities during the event and catch rates up to 12 months later.

The ability to maintain viable catches is likely to be influenced not only by extreme weather but also distributional shifts of key commercial species away from the major ports/landing sites and economic zones (Booth et al. 2011). Diminished access and property rights as distributions shift may become a significant issue in some regions, while other fishers may gain access to fish as they move (Hobday and Poloczanska 2010). Research on projecting these changes needs to be targeted in locations most likely to experience these shifts (e.g. southeast Australia), and species most likely to expand or contract their ranges. Some range-shifters may become 'locally invasive' as they move south (e.g. the long-spined sea urchin, Ling et al. 2009), impacting on habitats and fishery species. Research is needed on the impacts of these distributional shifts on important fisheries, as they are likely to occur in the short-term.

\section{What are the socio-economic implications?}

Grafton (2010) identifies communities with a high proportion of members employed in a particular capture fishery, low overall employment rates, low geographic mobility, and specialised skills as being most vulnerable to changes in their fisheries due to climate change. Such communities are likely to be small remote towns with fisheries as a main income source, e.g. Bowen in tropical Queensland and Kalbarri in Western Australia. As fisheries resources change, small-scale fisheries are less able to adapt due to their limited resources (Daw et al. 2009). Based on examples worldwide, fishing communities dependent on local resources of a limited number of species are more vulnerable to fluctuations in stocks, whether due to overfishing, climate change, or other causes (Brander 2010).

Madin et al. (2012) show that the socio-economic implications of range-shifting marine species in Australia include positive and negative effects on economic activities, human health, ecosystem services and management. They explored the potential for utilising different management tools in the Australian context, including spatial protection using no-take and multiple-use protected areas, and standard fisheries management tools. However, they concede that confidence is low in how fisheries management should most effectively deal with rangeshifting species. Although approaches to assess the economic and social resilience of fisheries to climate change are limited, one study identifies 12 economic resilience attributes for the rock lobster fishery in Tasmania across the business (e.g. profitability), sectoral (e.g. diversification) and governance (e.g. property rights) levels (van Putten et al. 2013). A more general set of indicators has been developed for adaptation of social systems to climate change that include perception of risk, ability to cope with change (financial and emotional flexibility), and livelihood diversity (Marshall et al. 2010). 
The socio-economic impacts of reduced fishing opportunities and depressed catches after tropical cyclones were found to be exacerbated in the GBR by a heavy reliance on high-value live coral trout limiting the industry's ability to adapt to change (Tobin et al. 2010). This reliance on a single species destined for a single market makes the fishery highly vulnerable to declines in catch rates. Sustained reductions in catch rates increased operating costs and reduced profit. In contrast, the recreational and charter fishing sectors employed temporary adaptation strategies (e.g. species diversification and fishing location shifts) and were not significantly impacted by the cyclones.

\section{How can fisheries adapt and what opportunities might exist?}

Fishers already live with and adapt to climate variation (Badjeck et al. 2010; Tobin et al. 2010), by moving the location and time that they fish, and the species they target. For example, fishers in the east coast longline fishery use a range of ports to land their catch, and change where they operate as fish distribution and availability changes (Hobday et al. 2009). Analogously, the Indian Ocean tsunami of 2004 impacted India, among other countries, and resulted in a revision of fisheries management in the south with an increased focus on livelihood diversification, coastal rather than offshore fisheries, and post-harvest employment opportunities (FAO 2010).

In Australia, the response of the GBR finfish fishery after tropical cyclones was a shortterm shift in effort, with large operators moving more than smaller ones (Tobin et al. 2010). No operators employed long-term adaptations, or diversified their target species due to lack of appropriate gear and the price differential between export live fish and domestic markets. Fisher surveys identified government support to: (i) provide access to locations closed to fishing, (ii) remove other management controls, (iii) provide low interest loans, and (iv) provide relief funds, as the best ways to minimise the impacts of cyclones on the fishery.

Climate change is expected to favour some fisheries species in Australia, such as warm temperate species, changing their distribution and relative abundance. For example, southern fisheries may have increased opportunities where tropical species move south, but lose opportunities where southern species contract (Hobday and Poloczanska 2010). If commercial fishers can change their harvest strategies and processing without incurring significant additional costs, travel time or associated fuel consumption, they may be able to take advantage of these opportunities. Diverting effort to target new or different species will be an important adaptation strategy as distributions shift (MacNeil et al. 2010). The capacity to quickly adapt to changing fisheries resources using new harvest techniques and gear will be a significant factor determining the future success of commercial fisheries (Badjeck et al. 2010). For example, if the distribution of southern bluefin tuna (Thunnus maccoyii) contracts south, as predicted, longline fishers would be expected to experience fewer seasonal area restrictions and be able to target other species (Hobday and Poloczanska 2010).

A blueprint for fisher communities recently developed emphasises the importance of understanding the combined role of climate and non-climate pressures in shaping marine sectors in small coastal communities to avoid maladaptation. Case studies (van Putten et al. 2014) clearly illustrate that local conditions are important and that adaptation options are mostly location and industry specific, while others are generally applicable across different coastal communities. Coastal management agencies can encourage marine industries to benefit from opportunities that arise from climate change, e.g. from new range shifting species, and create income and labour market opportunities for the charter and recreational sectors. Encouraging community level adaptation to the negative impacts of climate pressures can be 
found through identifying alternative species, diversification into other sectors, and professional and workforce mobility and flexibility.

\section{How can management adapt to maintain sustainable fisheries?}

The ability of fisheries to adapt and remain viable and sustainable under climate change will depend on the nature of current and future management strategies, with adaptive management frameworks identified as the most likely to succeed (Plaganyi et al. 2011a). In response to projected greater spatial and temporal variability in landings, fishers will have to become more mobile and responsive to fishing opportunities (Badjeck et al. 2010). This will require more flexible management and policy with an adaptive management paradigm, allowing for uncertainty (Brander 2010; Grafton 2010; Johnson and Welch 2010; OECD 2010). It has been suggested that climate change and overfishing can have significant synergistic impacts on fisheries (e.g. North Sea cod fishery, Kirby et al. 2009), while interactions between fishing, ocean warming and ocean acidification over time have shown that all three stressors synergistically impacted top predators and fish biomass in southeast Australia (Griffith et al. 2012). Improved fisheries and ecosystem management will be important for minimising other stressors and promoting more resilient fish stocks (Allison et al. 2009; Perry et al. 2010; Koehn et al. 2011). Many of the management improvements needed do not require new science or understanding; they require development of effective, responsive institutions and tools for achieving adaptive management (Brander 2010), and an ecosystem approach to fisheries management (OECD 2010; Hobday et al. 2011).

The range of adaptation options available for fisheries management to minimise the impacts of climate change include, but are not limited to: preserving age and geographic structure of fished populations; protecting key functional groups; multi-jurisdictional management of stocks; integrated management systems that include social, economic and ecological values; reducing overcapacity in fisheries; incorporating a climate change catch quota into stock assessments; and reducing barriers to adaptation, such as resource depletion and resource reliance (Badjeck et al. 2010; Johnson and Welch 2010; MacNeil et al. 2010). Specific planned adaptations can also reduce or delay impacts, or support autonomous adaptation in the short- to medium-term, such as focused management of target species, habitat protection and restoration, enhancement of native populations, assisted migration, and ex situ conservation (Koehn et al. 2011). Brander (2010) identifies focused fisheries management as being particularly important for populations at the edge of a species range. These populations can be valuable sources of genetic material to climate extremes but also have reduced surplus production, thus increasing their vulnerability to (previously tolerable) levels of fishing. Special protection should therefore be afforded to populations at the trailing edge of their range that may also experience the first impacts of climate change (e.g. increasing ocean temperature).

While the level of resource-dependency and socioeconomic circumstances will drive to some degree the most appropriate adaptation options, adapting to a changing climate will inevitably require trade-offs between biological assets and socioeconomic benefits (Koehn et al. 2011). Ultimately, difficult management decisions may need to be made that consider short-term costs and long-term gains, with preferable adaptations being those that are win:win in the short- and long-term ('no regrets' adaptations), or lose:win that secure future sustainability with some short-term costs (Grafton 2010).

Adaptive management frameworks - such as co-management and ecosystem approachesfocus on building adaptive capacity, reducing vulnerability and increasing socio-ecological resilience while promoting sustainable fisheries. These are all necessary attributes for coping 
with climate change (Daw et al. 2009). Madin et al. (2012) suggest that the application of frameworks that build resilience and adaptive capacity across the social-ecological system will be the optimal fisheries management response.

In cases where species managed under a quota system move to locations where fishers do not hold quota, designing a flexible framework and markets for trading (OECD 2010), or transferring quotas (Mcllgorm et al. 2010), may be options for overcoming the issue of access to a moving resource. Management may also need to consider strategies that allow for future projected changes, e.g. expansions of species ranges or changes in abundance (Koehn et al. 2011). Governments have an important role to play in identifying and removing institutional barriers to change, periodically reviewing protection measures to ensure they are still applicable, and ensuring that they do not dilute incentives for fishers to adapt to future climate change (OECD 2010).

\section{What are the barriers to adaptation?}

Adaptation of fisheries to external impacts is possible for even small sectors, and examination of examples of successful adaptations can provide valuable lessons regarding appropriate ways to manage fisheries in an uncertain future, and how to overcome barriers to adaptation (OECD 2010). Two reviews (Brander 2010; Johnson and Welch 2010) identify factors expected to limit the ability of fisheries to adapt to climate change: the projected rapid rate of change; the compromised health of overfished stocks; weak social and economic structures; a high dependence on fisheries; inflexible management regimes; and factors that undermine resilience, such as loss of biodiversity, habitat destruction, pollution, invasive species, and pathogens.

Uncertainty about future climate change encourages the use of short planning horizons that focus on immediate problems while delaying mitigation actions until more information becomes available (McIlgorm et al. 2010). To avoid this, Miller et al. (2010) propose focusing on integrated science that supports timely institutional responses, a broader planning perspective, and development of resilience-building strategies. Johnson and Welch (2010) propose an integrated assessment approach that can identify highly vulnerable species and targets for action, facilitating prioritisation of management effort and informed application of adaptation options (Koehn et al. 2011; Welch and Johnson 2013). However, despite recent progress towards studying marine social and ecological environments as coupled systems, many issues still challenge full integration (Perry and Ommer 2010).

Socioeconomic constraints are identified as significant barriers to fisheries adaptation (Mcllgorm 2010), particularly in the context of oceanic fishers (e.g. tuna) that have made long-term investments in fishing vessels, storage and processing. Future changes in the distribution and abundance of stocks due to climate change and the expected increases in fuel prices are likely to influence fishers' ability to travel greater distances to catch moving stocks, or change gear or practices to target different species. Modelling shows that, from an economic perspective, larger operators have an adaptive advantage that enables them to change their operation in response to fish redistributions (Fulton 2011). In contrast, family-based fishing operations have diminished adaptive capacity due to their long-term association with fishing that connects their identity with the activity and potentially limits their willingness to adopt adaptive strategies that involve occupational diversification (i.e. new income generating activities or leaving fisheries; Coulthard 2009).

Changes in fish stock distribution and the abundance of target and non-target (but potentially "new") species are likely to disrupt existing access and allocation arrangements (Daw et al. 2009; OECD 2010). In Australia, where fisheries are managed by a range of jurisdictions, climatic variations that lead to shifts in resource distribution may raise jurisdictional issues or 
limit flexibility to access cooperatively managed or shared resources. This was experienced in the North Pacific with the wild salmon fishery (Badjeck et al. 2010), and is projected to occur as Australia's east coast tuna stock move south, necessitating changes to the jurisdiction of the Australian fishery (Mcllgorm et al. 2010).

Significantly, overcoming barriers to change within the fishing industry will require ongoing involvement of the fishing industry in co-management and self-governance initiatives to assist governments meet the new flexible management paradigm (Mcllgorm et al. 2010). Incorporating multi-stakeholder participation, an ecosystem-based approach, a long-term perspective, and flexible livelihood and governance strategies into future fisheries management, will be key to effective adaptation to climate change (Plaganyi et al. 2011b) (Table 1).

\section{Conclusions}

Marine capture fisheries in Australia face significant future challenges associated with the impacts of climate change. However, adaptation options are available, and science can provide

Table 1 Summary of observed and anticipated climate change impacts on marine fisheries in Australia, socioeconomic implications and possible adaptations in the short-term (5-7 years), including barriers to adaptation. Likelihood of impacts and indirect effects, and confidence in the projections, are colour-coded based on the legend below. [Note: Likelihood and confidence scales follow those of Bell et al. (2011).]

\begin{tabular}{|c|c|c|c|c|}
\hline $\begin{array}{l}\text { Observed and } \\
\text { anticipated impacts }\end{array}$ & Indirect effects & $\begin{array}{l}\text { Socio-economic } \\
\text { implications }\end{array}$ & $\begin{array}{l}\text { Adaptation options (next 5- } \\
7 \text { years) }\end{array}$ & $\begin{array}{l}\text { Adaptation barriers (next } \\
5-7 \text { years) }\end{array}$ \\
\hline $\begin{array}{l}\text { Expansion of 'locally } \\
\text { invasive' species }\end{array}$ & $\begin{array}{l}\text { Reduced fishing days and } \\
\text { species catchability }\end{array}$ & $\begin{array}{l}\text { Economic declines or } \\
\text { losses (either due to } \\
\text { increasing costs or } \\
\text { declining catches) }\end{array}$ & $\begin{array}{l}\text { Spatially or temporally } \\
\text { flexible management }\end{array}$ & $\begin{array}{l}\text { Inflexible or jurisdiction- } \\
\text { driven management }\end{array}$ \\
\hline $\begin{array}{l}\text { Contraction of thermally } \\
\text { sensitive species to } \\
\text { smaller ranges }\end{array}$ & $\begin{array}{l}\text { Altered seasonality of } \\
\text { catches }\end{array}$ & $\begin{array}{l}\text { Loss of social identity } \\
\text { for communities with } \\
\text { long association with } \\
\text { fishing }\end{array}$ & $\begin{array}{l}\text { Financial support for } \\
\text { vulnerable fisheries (e.g. } \\
\text { low-interest loans or relief } \\
\text { funds) }\end{array}$ & $\begin{array}{l}\text { Weak socio-economic } \\
\text { structures (i.e. poor } \\
\text { financial or social support } \\
\text { systems) }\end{array}$ \\
\hline $\begin{array}{l}\text { Earlier age at maturity } \\
\text { and mortality }\end{array}$ & $\begin{array}{l}\text { Changes to catch } \\
\text { compositions, particularly in } \\
\text { fisheries that target sensitive } \\
\text { or specialist species }\end{array}$ & $\begin{array}{l}\text { Mental health issues } \\
\text { in highly dependent } \\
\text { communities }\end{array}$ & $\begin{array}{l}\text { Promote opportunities in } \\
\text { locations where stocks may } \\
\text { expand or increase in } \\
\text { abundance }\end{array}$ & $\begin{array}{l}\text { Lack of interest or political } \\
\text { will }\end{array}$ \\
\hline $\begin{array}{l}\text { Habitat loss and/or } \\
\text { degradation, particularly } \\
\text { of coral reefs and kelp } \\
\text { forests }\end{array}$ & $\begin{array}{l}\text { Reduced access to fisheries } \\
\text { stocks as distributions shift }\end{array}$ & $\begin{array}{l}\text { Trade-offs between } \\
\text { fisheries and other } \\
\text { sectors (e.g. water } \\
\text { supply and irrigation) }\end{array}$ & $\begin{array}{l}\text { Maintain sustainable } \\
\text { fisheries and healthy } \\
\text { supporting habitats }\end{array}$ & $\begin{array}{l}\text { Rapidity of the rate of } \\
\text { climate change }\end{array}$ \\
\hline
\end{tabular}

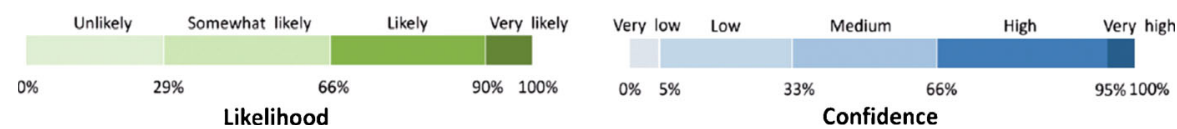

Likelihood: the probability that a future projection or prediction will occur based on expert judgment

Confidence: a quantitative or qualitative evaluation of the level of scientific understanding in support of a conclusion 
valuable information to inform decision-making. Improved projections of: (i) distributional shifts of key commercial fisheries species in locations vulnerable to climate change (e.g. southeast Australia); (ii) species most likely to expand or contract their ranges (e.g. warm temperate species); and, (iii) species that may become 'locally invasive'; are needed to inform management and support immediate adaptation of vulnerable sectors and communities. As species distributions shift, information is required to enable useful dialogue between management agencies that will need to work together in the future, particularly on how community dynamics might change and the likely social and economic impacts. Importantly, information is needed on economic or other factors that limit adaptation, and how these can be addressed for marine capture industries.

This review has considered a range of questions surrounding the impacts of climate change on commercial marine fisheries and adapting to change, with a focus on the Australian context and research over the past few years. Climate change is affecting, and will continue to affect, Australia's commercial marine fishing industries. With greater use of targeted information, industry can be better placed to adapt to future changes and take advantage of opportunities associated with the effects of climate change. It is important however to acknowledge the barriers to adaptation, as reducing these over the next 5-7 years will assist more effective adaptation planning. Efforts to reduce these barriers and synthesise learning from continued research will be critical to improve, or at least preserve, adaptive capacity for the future sustainability of marine capture fisheries.

Acknowledgments Funding from the Australian Government Department of Climate Change and Energy Efficiency, through the National Climate Change Adaptation Research Facility, supported this review. The authors thank the three anonymous reviewers for their insightful comments. We acknowledge helpful advice from Stewart Frusher and Ingrid van Putten, and assistance from Clare Brooker in collating the Endnote library.

Open Access This article is distributed under the terms of the Creative Commons Attribution License which permits any use, distribution, and reproduction in any medium, provided the original author(s) and the source are credited.

\section{References}

ABARES (2011) Australian fisheries statistics 2010. Australian Bureau of Agricultural and Resource Economics and Sciences, Canberra

Allison EH, Perry AL, Badjeck M-C et al (2009) Vulnerability of national economies to the impacts of climate change on fisheries. Fish Fish 10(2):173-196. doi:10.1111/j.1467-2979.2008.00310.x

Badjeck M-C, Allison EH, Halls AS, Dulvy NK (2010) Impacts of climate variability and change on fisherybased livelihoods. Mar Policy 34(3):375-383. doi:10.1016/j.marpol.2009.08.007

Balston J (2009a) An analysis of the impacts of long-term climate variability on the commercial barramundi (Lates calcarifer) fishery of north-east Queensland, Australia. Fish Res 99(2):83-89. doi:10.1016/j.fishres. 2009.05.001

Balston J (2009b) Short-term climate variability and the commercial barramundi (Lates calcarifer) fishery of north-east Queensland, Australia. Mar Freshw Res 60(9):912-923. doi:10.1071/mf08283

Barange M, Perry RI (2009) Physical and ecological impacts of climate change relevant to marine and inland capture fisheries and aquaculture. In: Cochrane K, Young CD, Soto D, Bahri T (eds) Climate change implications for fisheries and aquaculture: overview of current scientific knowledge. FAO Fisheries and Aquaculture Technical Paper No. 530. FAO, Rome, pp 7-106

Bell JD, Johnson JE, Hobday AJ (2011) Vulnerability of tropical Pacific fisheries and aquaculture to climate change. Secretariat of the Pacific community. Noumea, New Caledonia

Bell JD, Ganachaud AS, Gehrke PC, Griffiths SP, Hobday AJ, Hoegh-Guldberg O, Johnson JE, Le Borgne R, Lehodey P, Lough JM, Matear RJ, Pickering TD, Pratchett MS, Sen Gupta A, Waycott M (2013) Effects of 
climate change on tropical Pacific fisheries and aquaculture. Nat Clim Chang 3:591-599. doi:10.1038/ NCLIMATE1838

Booth DJ, Bond N, Macreadie P (2011) Detecting range shifts among Australian fishes in response to climate change. Mar Freshw Res 62(9):1027-1042. doi:10.1071/MF102701323-1650/11/091027

Brander K (2010) Impacts of climate change on fisheries. J Mar Syst 79(3-4):389-402. doi:10.1016/j.jmarsys. 2008.12.015

Brown CJ, Fulton EA, Hobday AJ et al (2010) Effects of climate-driven primary production change on marine food webs: implications for fisheries and conservation. Glob Chang Biol 16(4):1194-1212. doi:10.1111/j. 1365-2486.2009.02046.x

Campbell AH, Harder T, Nielsen S, Kjelleberg S, Steinberg PD (2011) Climate change and disease: bleaching of a chemically defended seaweed. Glob Chang Biol 17(9):2958-2970. doi:10.1111/j. 1365-2486.2011.02456.x

Cheung WWL, Lam VWY, Sarmiento JL, Kearney K, Watson R, Zeller D, Pauly D (2010) Large-scale redistribution of maximum fisheries catch potential in the global ocean under climate change. Glob Chang Biol 16(1):24-35. doi:10.1111/j.1365-2486.2009.01995.x

Cheung WWL, Dunne J, Sarmiento JL, Pauly D (2011) Integrating ecophysiology and plankton dynamics into projected maximum fisheries catch potential under climate change in the Northeast Atlantic. ICES J Mar Sci: J Cons 68(6):1008-1018. doi:10.1093/icesjms/fsr012

Cheung WWL, Watson R, Pauly D (2013) Signature of ocean warming in global fisheries catch. Nature 497: 365-369. doi:10.1038/nature 12156

Coulthard S (2009) Adaptation and conflict within fisheries: insights for living with climate change. In: Adger WN, Lorenzoni I, O’Brien K (eds) Adapting to climate change: thresholds, values, governance. Cambridge University Press, Cambridge, pp 255-268

Dang V, Speck P, Benkendorff K (2012) Influence of elevated temperatures on the antiviral and antibacterial immune response of abalone Haliotis rubra. Fish Shellfish Immunol 32:732-740. doi:10.1016/j.fsi.2012.01.022

Danovaro R, Corinaldesi C, Dell'Anno A, Fuhrman JA, Middelburg JJ, Noble RT, Suttle CA (2010) Marine viruses and global climate change. FEMS Microbiol Rev 35:993-1034. doi:10.1111/j.1574-6976.2010. 00258.x

Daw T, Adger W, Brown K, Badjeck M (2009) Climate change and capture fisheries. Worldfish Centre Report

Donnelly R (2011) Climate change vulnerability assessment: Queensland Marine Aquarium Supply Industry, 2010. Research Publication no. 108

FAO (2010) State of world fisheries and aquaculture 2010. FAO Fisheries and Aquaculture Department, Rome

Froese R, Binohlan C (2000) Empirical relationships to estimate asymptotic length, length at first maturity and length at maximum yield per recruit in fishes, with a simple method to evaluate length frequency data. J Fish Biol 56:758-773

Fulton EA (2011) Interesting times: winners, losers, and system shifts under climate change around Australia. ICES J Mar Sci 68(6):1329-1342. doi:10.1093/icesjms/fsr032

Gardner JL, Peters A, Kearney MR, Joseph L, Heinsohn R (2011) Declining body size: a third universal response to warming? Trends Ecol Evol 26(6):285-291

Gillson J, Scandol J, Suthers I (2009) Estuarine gillnet fishery catch rates decline during drought in eastern Australia. Fish Res 99(1):26-37. doi:10.1016/j.fishres.2009.04.007

Grafton RQ (2010) Adaptation to climate change in marine capture fisheries. Mar Policy 34(3):606-615. doi:10. 1016/j.marpol.2009.11.011

Griffith GD, Fulton EA, Gorton R, Richardson AJ (2012) Predicting interactions among fishing, ocean warming, and ocean acidification in a marine system with whole-ecosystem models. Conserv Biol. doi:10.1111/j.15231739.2012.01937.x

Hallegraeff GM (2010) Ocean climate change, phytoplankton community responses, and harmful algal blooms: a formidable predictive challenge. J Phycol 46(2):220-235. doi:10.1111/j.1529-8817.2010.00815.x

Hobday AJ (2010) Ensemble analysis of the future distribution of large pelagic fishes off Australia. Prog Oceanogr 86(1-2):291-301

Hobday AJ, Poloczanska ES (2010) Marine fisheries and aquaculture. In: Stokes C, Howden M (eds) Adapting agriculture to climate change: preparing Australian agriculture, forestry and fisheries for the future. CSIRO Publishing, Collingwood, pp 205-228

Hobday AJ, Mapstone B, Connolly R, Hughes T, Marshall P, McDonald J, Waschka M (2009) Enhancing species adaptation to climate change. Marine climate change in Australia; Impacts and adaptation responses

Hobday AJ, Smith ADM, Stobutzki IC et al (2011) Ecological risk assessment for the effects of fishing. Fish Res 108(2-3):372-384

Holbrook NJ, Bindoff NL (1997) Interannual and decadal temperature variability in the southwest Pacific Ocean between 1955 and 1988. J Clim 10:1035-1049 
Ian Perry R, Ommer RE (2010) Introduction: coping with global change in marine social-ecological systems. Mar Policy 34(4):739-741. doi:10.1016/j.marpol.2010.01.025

Ives MC, Scandol JP, Montgomery SS, Suthers IM (2009) Modelling the possible effects of climate change on an Australian multi-fleet prawn fishery. Mar Freshw Res 60(12):1211-1222. doi:10.1071/mf07110

Johnson JE, Welch DJ (2010) Marine fisheries management in a changing climate: a review of vulnerability and future options. Rev Fish Sci 18(1):106-124. doi:10.1080/10641260903434557

Johnson JE, Holbrook NJ (2014) Adaptation of Australia's marine ecosystems to climate change: Using science to inform conservation management. Int J Ecol. doi:org/10.1155/2014/140354

Johnson CR, Banks SC, Barrett NS et al (2011) Climate change cascades: Shifts in oceanography, species' ranges and subtidal marine community dynamics in eastern Tasmania. J Exp Mar Biol Ecol 400(1-2):17-32. doi: 10.1016/j.jembe.2011.02.032

Kirby RR, Beaugrand G, Lindley JA (2009) Synergistic effects of climate and fishing in a marine ecosystem. Ecosystems 12(4):548-561. doi:10.1007/s10021-009-9241-9

Koehn JD, Hobday AJ, Pratchett MS, Gillanders BM (2011) Climate change and Australian marine and freshwater environments, fishes and fisheries: synthesis and options for adaptation. Mar Freshw Res 62(9):1148-1164

Last PR, White WT, Gledhill DC, Hobday AJ, Brown R, Edgar GJ, Pecl G (2011) Long-term shifts in abundance and distribution of a temperate fish fauna: a response to climate change and fishing practices. Glob Ecol Biogeogr 20:58-72. doi:10.1111/j.1466-8238.2010.00575.x

Ling SD, Johnson CR, Ridgway K, Hobday AJ, Haddon M (2009) Climate-driven range extension of a sea urchin: inferring future trends by analysis of recent population dynamics. Glob Chang Biol 15(3):719-731. doi:10.1111/j.1365-2486.2008.01734.x

MacNeil MA, Graham NAJ, Cinner JE, Dulvy NK, Loring PA, Jennings S, Polunin NVC, Fisk AT, McClanahan TR (2010) Transitional states in marine fisheries: adapting to predicted global change. Philos Trans R Soc B: Biol Sci 365(1558):3753-3763. doi:10.1098/rstb.2010.0289

Madin EMP, Ban NC, Doubleday ZA, Holmes TH, Pecl GT, Smith F (2012) Socio-economic and management implications of range-shifting species in marine systems. Glob Environ Chang-Hum Policy Dimens 22(1): 137-146. doi:10.1016/j.gloenvcha.2011.10.008

Mapstone B, Appleford P, Broderick K, Connolly R, Higgins J, Hobday A, Hughes T, Marshall P, McDonald J, Waschka M (2010) National climate change adaptation research plan for marine biodiversity and resources. National climate change adaptation research. Facility, Gold Coast

Marshall NA, Marshall PA, Tamelander J, Obura D, Malleret-King D, Cinner JE (2010) A framework for social adaptation to climate change; Sustaining tropical coastal communities and industries. IUCN, Gland, v +36 $\mathrm{pp}$

McIlgorm A (2010) Economic impacts of climate change on sustainable tuna and billfish management: insights from the Western Pacific. Prog Oceanogr 86(1-2):187-191. doi:10.1016/j.pocean.2010.04.024

McIlgorm A, Hanna S, Knapp G, Le Floc'H P, Millerd F, Pan M (2010) How will climate change alter fishery governance? Insights from seven international case studies. Mar Policy 34(1):170-177. doi:10.1016/j. marpol.2009.06.004

Meynecke JO, Lee SY (2011) Climate-coastal fisheries relationships and their spatial variation in Queensland, Australia. Fish Res 110(2):365-376. doi:10.1016/j.fishres.2011.05.004

Miller K, Charles A, Barange M et al (2010) Climate change, uncertainty, and resilient fisheries: institutional responses through integrative science. Prog Oceanogr 87(1-4):338-346

Munday PL, Leis JM, Lough JM, Paris CB, Kingsford MJ, Berumen ML, Lambrechts J (2009) Climate change and coral reef connectivity. Coral Reefs 28(2):379-395. doi:10.1007/s00338-008-0461-9

Neuheimer AB, Thresher RE, Lyle JM, Semmens JM (2011) Tolerance limit for fish growth exceeded by warming waters. Nat Clim Chang. doi:10.1038/NCLIMATE1084

OECD (2010) The economics of adapting fisheries to climate change. OECD Publishing, Paris. doi:10.1787/ 9789264090415-en

Pearce A, Lenanton R, Jackson G, Moore J, Feng M, Gaughan D (2011) The "marine heat wave" off Western Australia during the summer of 2010/11. Fisheries Research Report No. 222. Western Australia

Pecl G, Frusher S, Gardner C, Haward M, Hobday A, Jennings S, Nursey-Bray M, Punt A, Revill H, van Putten I (2009) The east coast Tasmanian rock lobster fishery - vulnerability to climate change impacts and adaptation response options. Report to the Department of Climate Change, Australia

Perry RI, Ommer RE, Barange M, Werner F (2010) The challenge of adapting marine social-ecological systems to the additional stress of climate change. Curr Opin Environ Sustain 2(5-6):356-363. doi:10.1016/j.cosust. 2010.10 .004

Pitt NR, Poloczanska ES, Hobday AJ (2010) Climate-driven range changes in Tasmanian intertidal fauna. Mar Freshw Res 61(9):963-970. doi:10.1071/mf09225 
Plaganyi EE, Weeks SJ, Skewes TD, Gibbs MT, Poloczanska ES, Norman-Lopez A, Blamey LK, Soares M, Robinson WML (2011a) Assessing the adequacy of current fisheries management under changing climate: a southern synopsis. ICES J Mar Sci 68(6):1305-1317. doi:10.1093/icesims/fsr049

Plaganyi EE, Bell JD, Bustamante RH et al (2011b) Modelling climate-change effects on Australian and Pacific aquatic ecosystems: a review of analytical tools and management implications. Mar Freshw Res 62(9):11321147

Poloczanska ES, Hobday AJ, Richardson AJ (eds) (2009) Report Card of Marine Climate Change for Australia. NCCARF Publication 05/09, ISBN 978-1-921609-03-9

Poloczanska ES, Hobday AJ, Richardson AJ (eds) (2012) Marine Climate Change in Australia, Impacts and Adaptation Responses. 2012 Report Card, ISBN 978-0-643-10927-8

Pörtner HO, Peck MA (2010) Climate change effects on fishes and fisheries: towards a cause-and-effect understanding. J Fish Biol 77(8):1745-1779. doi:10.1111/j.1095-8649.2010.02783.x

Pratchett M, Wilson S, Graham N, Munday M, Jones G, Polunin N (2009) Multi-scale temporal effects of climate-induced coral bleaching on motile reef organisms. In: Oppen MV, Lough J (eds) Coral bleaching: patterns and processes, causes and consequences. Springer, Heidelberg, pp 139-158

Pratchett MS, Bay LK, Gehrke PC, Koehn JD, Osborne K, Pressey RL, Sweatman HPA, Wachenfeld D (2011a) Contribution of climate change to degradation and loss of critical fish habitats in Australian marine and freshwater environments. Mar Freshw Res 62(9):1062-1081. doi:10.1071/mf10303

Pratchett M, Munday P, Graham N et al (2011b) Vulnerability of coastal fisheries in the tropical Pacific to climate change. In: Bell JD, Johnson JE, Hobday AJ (eds) Vulnerability of tropical pacific fisheries and aquaculture to climate change. Secretariat for the Pacific Community, Noumea

Ridge-Partners (2010) Overview of the Australian fishing and aquaculture industry: present and future. A report supporting the development of Working Together: the National Fishing and Aquaculture RD\&E Strategy. Copyright Fisheries Research and Development Corporation and Ridge Partners

Ridgway KR (2007) Long-term trend and decadal variabiity of the southward penetration of the East Australian Current. Geophys Res Lett 34(13):L13613. doi:10.1029/2007GL030393

Stuart-Smith RD, Barrett NS, Stevenson DG, Edgar GJ (2009) Stability in temperate reef communities over a decadal time scale despite concurrent ocean warming. Glob Chang Biol 16(1):122-134. doi:10.1111/j.13652486.2009.01955.x

Tobin A, Schlaff A, Tobin R, Penny A, Ayling T, Ayling A, Krause B, Welch D, Sutton S, Sawynok B, Marshall N, Marshall P (2010) Adapting to change: minimising uncertainty about the effects of rapidly-changing environmental conditions on the Queensland Coral Reef Finfish Fishery. Final Report to the Fisheries Research \& Development Corporation, Project 2008/103. Fishing \& Fisheries Research Centre Technical Report No. 11, James Cook University, Townsville, Australia (172pp.)

van Putten IE, Jennings S, Frusher S, Gardner C, Haward M, Hobday A, Nursey-Bray M, Pecl G, Punt A, Revill $\mathrm{H}$ (2013) Building blocks of economic resilience to climate change: a fisheries example. Reg Environ Chang. doi:10.1007/s10113-013-0456-0

van Putten I, Metcalf S, Frusher S, Marshall N, Tull M (2014) Transformation of coastal communities: Where is the marine sector heading? Australasian Journal of Regional Studies (in press)

Welch DJ, Johnson JE (2013) Assessing the vulnerability of Torres Strait fisheries and supporting habitats to climate change. Report to the Australian Fisheries Management Authority. C2O Fisheries, Australia, 114pp

Wernberg T, Russell BD, Thomsen MS, Gurgel CFD, Bradshaw CJA, Poloczanska ES, Connell SD (2011) Seaweed communities in retreat from ocean warming. Curr Biol 21(21):1828-1832. doi:10.1016/j.cub.2011. 09.028

Wilson SK, Adjeroud M, Bellwood DR et al (2010) Crucial knowledge gaps in current understanding of climate change impacts on coral reef fishes. J Exp Biol 213(6):894-900. doi:10.1242/jeb.037895 